\title{
Effects of recycled concrete aggregate on the fresh properties of self-consolidating concrete
}

\author{
MD. SAFIUDDIN \\ Department of Civil and Environmental Engineering, Faculty of Engineering, \\ University of Waterloo, 200 University Avenue West, Waterloo, Ontario, Canada N2L 3G1.
}

M.A. SALAM, M.Z. JUMAAT

Department of Civil Engineering, Faculty of Engineering, University of Malaya, 50603 Kuala Lumpur, Malaysia.

\begin{abstract}
Concrete wastes are generally delivered to the landfill sites for disposal. Due to increasing charges of landfill and scarcity of natural coarse aggregate (NCA), recycled concrete aggregate (RCA) derived from concrete wastes is growing interest in construction industry. In the present study, RCA was used as partial and full replacements of NCA to produce self-consolidating concrete (SCC). Different SCC mixes were produced with RCA substituting $0 \%, 30 \%, 50 \%, 70 \%$, and $100 \%$ NCA by weight. The water to cement (W/C) ratio and highrange water reducer (HRWR) dosage were kept the same for all concretes. The effects of RCA on the key fresh properties such as filling ability, passing ability, and segregation resistance of SCC were investigated. The test results revealed that the filling ability and passing ability of SCC were improved for 30\% and 50\% RCA. The SCC mixes with $30 \%$ and 50\% RCA also possessed adequate segregation resistance. In addition, strong correlations were observed for filling ability, passing ability, and segregation resistance. The overall test results suggest that RCA can be used to produce SCC substituting up to 50\% NCA without affecting the key fresh properties of concrete.
\end{abstract}

Keywords: filling ability, passing ability, recycled concrete aggregate, segregation resistance, selfconsolidating concrete

\section{Introduction}

Self-consolidating concrete (SSC) is a highly flowing concrete that spreads through congested reinforcement, fills every corner of the formwork, and gets consolidated under self-weight [11]. The concept of SCC was proposed in 1986 by Professor Okamura [18], and the first prototype was developed in Japan in 1988 by Professor Ozawa [19]. However, the development of SCC was first reported in 1989 [17]. By the early 1990 's, Japan started to produce and use SCC commercially. Since its inception, SCC has been widely used in large construction in Japan [18]. Globally, the use of SCC in civil engineering structures has been remarkably increased over the last two decades.

The basic ingredients of SCC are similar to those of normal concrete. The traditional concrete aggregates such as gravel or crushed stone, and river or mining sand are also used in SCC. Generally, the aggregates occupy 55-60\% of the SCC volume 
[18] and play a substantial role in determining the workability, strength, dimensional stability, and durability of concrete. The aggregates also have a significant effect on the cost of SCC. Therefore, less expensive aggregates are desirable for use in SCC. In addition, there is a critical shortage of natural aggregates in many regions of the world due to construction boom in developing countries and re-construction in developed countries [28]. Consequently, there is a growing interest in using alternative aggregates in construction. In the recent decade, the recycled concrete aggregate (RCA) obtained from concrete wastes has been used in the production of new concrete. The scarcity of natural coarse aggregate (NCA) and the increasing charges for landfill have encouraged the use of RCA in concrete [10]. In addition, the increased distance between the sources of natural aggregates and construction sites has constrained the contractors to consider RCA as an alternative of NCA [8].

A large quantity of concrete wastes often generates from demolished old structures, tested concrete, and excess or returned concrete. The removal and disposal of these wastes cause significant environmental problems. In this context, the recycling of concrete wastes as RCA is important because it can minimize the environmental pollution and reduce the huge consumption of natural aggregates in construction. Many researchers have shown that RCA can be a reliable alternative of NCA in construction, particularly for non-structural application [23]. Levy and Helene [15] as well as Poon et al. [21] have graded RCA as potentially good for use in new concrete. Properly processed RCA can be used to produce new concrete for pavements, shoulders, barriers, embankments, sidewalks, curbs, gutters, and bridge foundations. It can also be used in structural grade concrete, bituminous concrete, and soil-cement pavement bases [22]. Moreover, RCA has been used to produce durable and sustainable concretes [9, 26]. In comparison, limited studies have been conducted to use RCA in SCC. Recently, Tu et al. [27], Kou and Poon [14], and Grdic et al. [8] have produced SCC using RCA as partial and full replacements of NCA. However, these studies gave more emphasis on the hardened properties and no comprehensive study investigated the effects of RCA on the key fresh properties of SCC. Also, no studies were carried out to produce SCC using RCA derived from tested and excess or returned concretes.

In the present study, the RCA derived from tested concrete was used to produce SCC substituting 0-100\% NCA by weight. The effects of RCA on the key fresh properties such as filling ability, passing ability, and segregation resistance of SCC were observed. The research outcome shows that SCC possessing good filling and passing abilities and adequate segregation resistance can be produced using RCA up to 50\% replacement of NCA.

\section{Research significance}

Demolished old structures, tested concrete, and excess or returned concrete create a huge amount of concrete wastes, thus causing a substantial disposal problem. Since such disposal problem is becoming more and more difficult particularly in many densely 
populated countries, a proper waste management needs to be practised. Indeed, the shortage of land and the increasing charges for landfill require recycling of concrete wastes to produce RCA as a means of the waste management process. Moreover, there is a critical shortage of natural aggregates in many regions of the world. The use of RCA in SCC will contribute not only to find a solution for the disposal problem caused by the concrete wastes but also to reduce the demand for natural aggregates. In addition, the use of RCA in SCC will reduce the environmental impact due to the harvesting and processing of virgin aggregates from natural resources.

\section{Materials and methods}

\subsection{Materials}

Three types of aggregates such as NCA, RCA, and mining sand were used. NCA and RCA acted as the coarse aggregate (CA), whereas mining sand performed as the fine aggregate (FA). The NCA used was crushed granite stone. RCA was derived from the tested 50-MPa concrete cubes (water to cement (W/C) ratio: 0.40; age: 6 months) that contained well-graded crushed granite stone (maximum size: $20 \mathrm{~mm}$ ), and had a density of $2270 \mathrm{~kg} / \mathrm{m}^{3}$ and a porosity of $11 \%$. The concrete cubes were crushed to the specified size and gradation of NCA using a hammer. The nominal maximum size of NCA and RCA was $20 \mathrm{~mm}$, and that of FA was $5 \mathrm{~mm}$. NCA, RCA, and FA were sieved to meet the ASTM specifications [1].

Table 1. Basic physical properties of fine and coarse aggregates

\begin{tabular}{|c|c|c|c|}
\hline Physical property & RCA & NCA & FA \\
\hline Saturated surface-dry based specific gravity & 2.51 & 2.62 & 2.69 \\
\hline Oven-dry based specific gravity & 2.46 & 2.53 & - \\
\hline Absorption (wt. \%) & 1.91 & 0.60 & 1.32 \\
\hline Moisture content (wt. \%) & 1.32 & 0.17 & 0.31 \\
\hline Compacted bulk density (kg/m ${ }^{3}$ ) & 1366.2 & 1513 & 1618.5 \\
\hline Angularity number & 9.47 & 7.45 & - \\
\hline Fines (<4.75 mm) from aggregates ${ }^{*}$ (wt. \%) & 7.75 & - & - \\
\hline
\end{tabular}

*After 1-min mixing with an equal amount of fine aggregate

The basic physical properties of the aggregates are shown in Table 1 . The gradation curves of the aggregates are presented in Figure 1. The size distributions of FA, NCA, and RCA were within the ASTM limits, as shown in Figure 1. RCA was more angular than NCA and therefore possessed a higher angularity number (Table 1). In addition, RCA had porous surfaces consisting of reclaimed mortar and thus possessed a higher absorption value than NCA (Table 1). The surface roughness of RCA was also greater than that of NCA. The visual inspection of aggregates revealed the greater angularity, surface roughness, and surface porosity of RCA (Figure 2). Also, the surface hardness of RCA was less than that of NCA due to porous reclaimed mortar. Hence, RCA con- 
tributed to increase the fines content because of abrasive mixing action. In the present study, it was found that $7.75 \%$ fines finer than No. 4 sieve were generated from RCA when it was mixed for 1-min with an equal amount of mining sand. This mixing time was used since the aggregates were initially mixed for $1 \mathrm{~min}$ before adding the cement and water during preparation of SCC mixes.

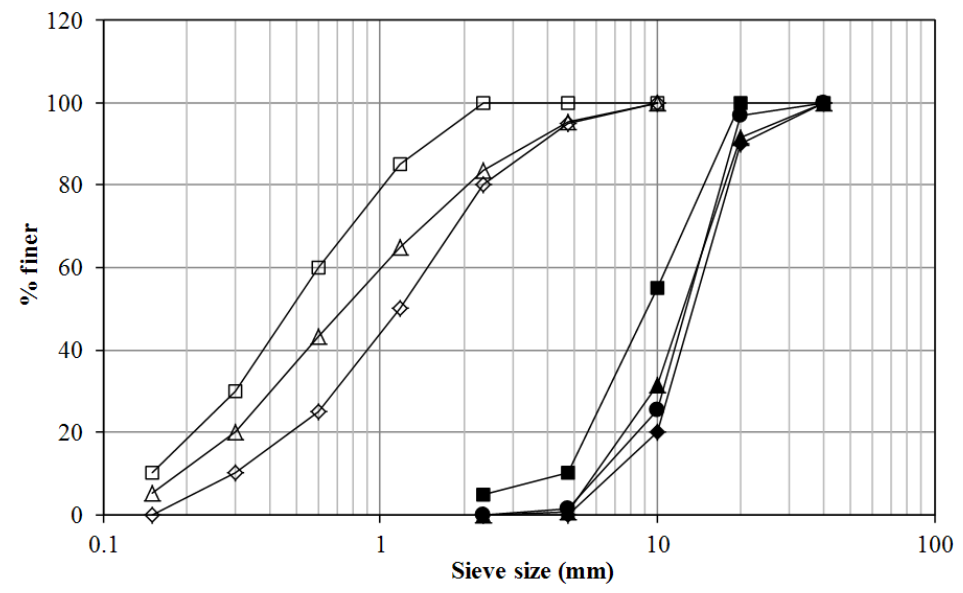

$\begin{array}{ll}\triangle \text { Fine aggregate (FA) } & \square \text { FA upper bound } \\ \diamond \text { FA lower bound } & - \text { Natural coarse aggregate (NCA) } \\ - \text {-NCA upper bound } & - \text { NCA lower bound } \\ - \text {-Recycled concrete aggregate (RCA) } & \end{array}$

Figure 1. Size distributions of FA, NCA, and RCA
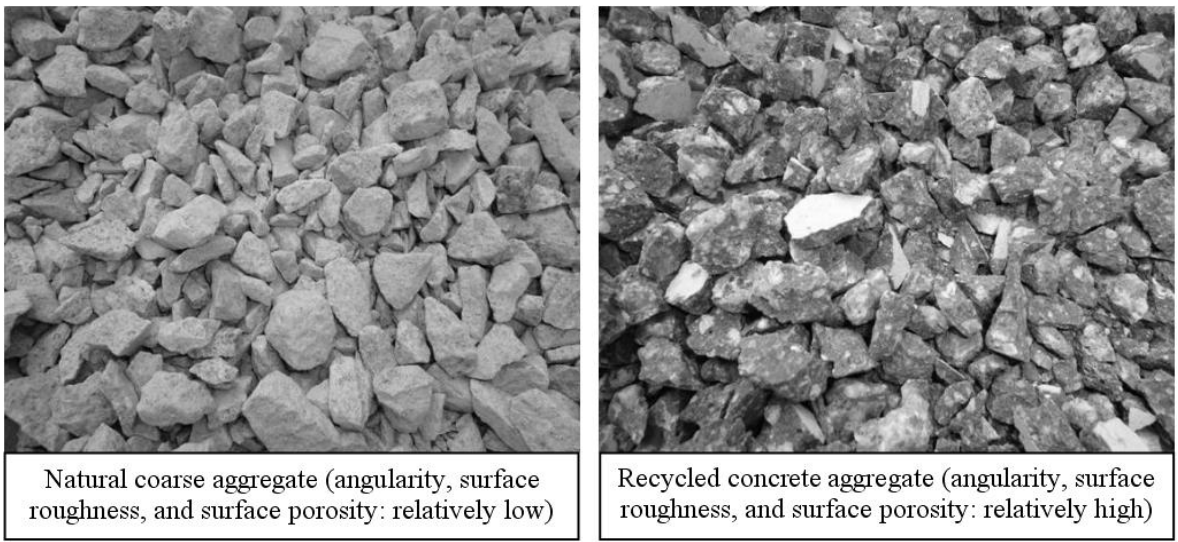

Figure 2. Visual appearances of natural and recycled concrete aggregates

The aggregates were bound together by means of paste, which contained cement and water. ASTM Type I portland cement (C) was used as the binder. The mix water 
(W) used was normal tap water. Also, a polycarboxylate-based high-range water reducer (HRWR) was used with an adequate dosage to obtain the required filling ability and passing ability of SCC without any segregation. The specific gravity of cement was 3.12 and that of HRWR was 1.06. The solid content of HRWR was $13.5 \%$, which aided to calculate its water contribution to concrete mix.

\subsection{Concrete mix proportions}

Nine trial concrete mixes using NCA were prepared with different W/C ratios $(0.50$, 0.60, and 0.65) and HRWR dosages. The basic mix proportions (without HRWR dosage) of these concretes were determined based on the British DoE mix design method [5]. From the trial concrete mixes, a suitable control mix satisfying the workability (filling ability, passing ability, and segregation resistance) requirements of SCC was decided. The W/C ratio and HRWR dosage of the selected control mix was 0.60 and $1.5 \%$ of cement by weight, respectively. Using the same W/C ratio and HRWR dosage, four different concretes were produced with RCA substituting 30\%, 50\%, 70\%, and $100 \%$ NCA by weight. The basic mix proportions of these concretes were calculated based on the absolute volume of constituent materials and $2 \%$ entrapped air content. The W/C ratio and HRWR dosage of these concretes were kept the same as used in the control mix ( $0 \% \mathrm{RCA})$ to observe the effects of RCA. The mix proportions of control and RCA concretes are shown in Table 2.

Table 2. Mix proportions of different SCC mixes (volume of concrete: $1 \mathrm{~m}^{3}$ )

\begin{tabular}{|c|c|c|c|c|c|c|c|c|c|}
\hline Mix & $\begin{array}{c}\text { RCA } \\
\left(\% \text { CA }^{*}\right)\end{array}$ & $\begin{array}{c}\text { W/C } \\
\text { ratio }\end{array}$ & $\begin{array}{c}\text { FA/TA }^{\dagger} \\
\text { ratio }\end{array}$ & $\begin{array}{c}\text { HRWR } \\
(\% \mathrm{C})\end{array}$ & $\begin{array}{c}\mathrm{W} \\
(\mathrm{kg})\end{array}$ & $\begin{array}{c}\mathrm{C} \\
(\mathrm{kg})\end{array}$ & $\begin{array}{c}\text { FA } \\
(\mathrm{kg})\end{array}$ & $\begin{array}{c}\text { NCA } \\
(\mathrm{kg})\end{array}$ & $\begin{array}{c}\text { RCA } \\
(\mathrm{kg})\end{array}$ \\
\hline CR0 & 0 & 0.60 & 0.50 & 1.50 & 205 & 342 & 914 & 914 & 0 \\
\hline CR30 & 30 & 0.60 & 0.50 & 1.50 & 205 & 342 & 873.4 & 611.7 & 262.1 \\
\hline CR50 & 50 & 0.60 & 0.50 & 1.50 & 205 & 342 & 870 & 435 & 435 \\
\hline CR70 & 70 & 0.60 & 0.50 & 1.50 & 205 & 342 & 866.2 & 259.9 & 606.3 \\
\hline CR100 & 100 & 0.60 & 0.50 & 1.50 & 205 & 342 & 860.5 & 0 & 860.5 \\
\hline
\end{tabular}

${ }^{*} \mathrm{CA}=\mathrm{NCA}+\mathrm{RCA} ;{ }^{\dagger} \mathrm{TA}=\mathrm{FA}+\mathrm{CA}$

The concretes were designated based on the RCA content. For example, the CR50 designation was used for a concrete including 50\% RCA content.

\subsection{Preparation of concretes}

Air-dry fine and coarse aggregates were used in preparing the concretes. These aggregates absorbed some water at the time of mixing. In contrast, the liquid HRWR contributed some water during mixing. Therefore, the proportions of aggregates and mix water were corrected before mixing the constituent materials of concrete.

The mixing sequence and duration are very important in the production of SCC, as they influence the workability of concrete. In the present study, the coarse and fine 
aggregates were first charged into a revolving pan-type concrete mixer and mixed with one-third of the mix water for $60 \mathrm{~s}$. Then the mixer was stopped for $60 \mathrm{~s}$ to increase the wetness of aggregates. After this first rest period, the cement was added followed by the second one-third of the mix water and the mixing action was continued for $120 \mathrm{~s}$. The mixer was stopped thereafter and allowed for a second rest period of $180 \mathrm{~s}$. During the first and second rest periods, the mixer was covered with a piece of wet burlap to minimize the evaporation of water. Finally, the remaining one-third of the mix water blended with the HRWR dosage was added and the mixing operation was continued for $180 \mathrm{~s}$ to produce the fresh concretes.

\subsection{Test methods and procedures}

The filling ability, passing ability, and segregation resistance are the key fresh properties of SCC. Immediately after the completion of mixing, the freshly mixed SCC mixes were tested to determine these three fresh properties.

\subsubsection{Filling ability tests}

The filling ability is defined as the ability of SCC to flow in unconfined condition and fill every corner of the formwork under self-weight. In the present study, the filling ability was measured with respect to slump flow, $T_{50}$ slump flow time, and V-funnel flow time. The slump flow was determined according to the test method given in ASTM C 1611/C 1611M [3]. The slump flow test assesses the horizontal free flow of SCC in the absence of obstructions. This test also judges the capability of concrete to flow under its self-weight [7].

The $T_{50}$ slump flow time was determined according to the test method given in EFNARC guidelines and specifications [6]. In this test, the time that a concrete sample requires for a spread of $50 \mathrm{~cm}$ diameter is determined. This time is well-known as $T_{50}$, which gives an indication for the relative viscosity of SCC mix. The rate of concrete spreading is inversely proportional to its viscosity. Thus, the $T_{50}$ slump flow time provides a relative assessment of the unconfined flow rate of concrete.

The V-funnel flow time $\left(T_{V}\right)$ was determined following the procedure given in EFNARC specifications and guidelines [6]. In this test, the time that a concrete sample needs for flowing out of a V-shaped box is determined to measure the filling ability of SCC. The shorter the flow time, the greater is the filling ability. This test also provides a qualitative assessment of the relative viscosity of SCC and indicates the blocking effect caused by segregation [25]. A shorter flow time suggests a lower viscosity, whereas a prolonged flow time indicates the blocking susceptibility of the mix [6].

\subsubsection{Passing ability test}

The passing ability is defined as the ability of SCC to flow in confined condition and completely fill all spaces within the formwork under self-weight and without any 
vibration. In the present study, the passing ability was determined with respect to J-ring flow (JF) following the test method depicted in EFNARC specifications and guidelines [6]. In addition, the blocking index (BI: difference between slump flow and J-ring flow, SF-JF) was determined to assess blocking resistance as well as passing ability. A lower blocking index suggests a greater blocking resistance and a higher passing ability.

\subsubsection{Segregation tests}

Segregation resistance plays an important role in SCC. Poor segregation resistance would cause less flowing ability and significant blockage around congested reinforcement [11]. SCC must have good segregation resistance for application in structural members. In the present study, the Japanese sieve stability and column segregation tests were carried out to determine the segregation resistance of SCC mixes. The Japanese sieve stability test was conducted according to the procedure given by Nagataki and Fujiwara [16]. In this test, the mortar mass passing through a No. 4 sieve was expressed as the percentage of the total mortar content of original concrete sample to quantify the segregation resistance of SCC with respect to segregation index (SI).

The column segregation test was conducted following the procedure given in ASTM C 1610/C 1610M [2]. In this test, the saturated surface-dry based mass difference of coarse aggregates collected from the top and bottom sections of a column apparatus was expressed as the percentage of the average aggregate content of concrete for both sections to measure the segregation resistance of SCC with regard to segregation ratio (SR).

\section{Results and discussion}

The test results for the filling ability (slump flow, $T_{50}$ slump flow time, and V-funnel flow time), passing ability (J-ring flow and blocking index), and segregation resistance (segregation index and segregation ratio) of various SCC mixes are given in Table 3. It is obvious from Table 3 that the presence of RCA significantly influenced the filling ability, passing ability, and segregation resistance of SCC. The mix parameters that influenced these three properties of SCC are shown in Table 4.

Table 3. Fresh properties of various SCC mixes

\begin{tabular}{|c|c|c|c|c|c|c|c|}
\hline \multirow[b]{2}{*}{ Concrete } & \multicolumn{3}{|c|}{ Filling ability } & \multicolumn{2}{|c|}{ Passing ability } & \multicolumn{2}{|c|}{ Segregation resistance } \\
\hline & $\begin{array}{l}\text { Slump } \\
\text { flow, SF } \\
(\mathrm{mm})\end{array}$ & $\begin{array}{l}T_{50} \text { slump } \\
\text { flow time } \\
\text { (s) }\end{array}$ & $\begin{array}{c}\mathrm{V} \text {-funnel } \\
\text { flow time, } \\
T_{V}(\mathrm{~s})\end{array}$ & $\begin{array}{c}\text { J-ring } \\
\text { flow, } \\
\text { JF (mm) }\end{array}$ & $\begin{array}{c}\text { Blocking } \\
\text { index, } \\
\text { BI (mm) }\end{array}$ & $\begin{array}{c}\text { Segrega- } \\
\text { tion index, } \\
\text { SI }(\%)\end{array}$ & $\begin{array}{c}\text { Segrega- } \\
\text { tion ratio, } \\
\text { SR }(\%)\end{array}$ \\
\hline CR0 & 620 & 3.1 & 7.3 & 580 & 40 & 9.8 & 11.7 \\
\hline CR30 & 640 & 2.9 & 7.1 & 610 & 30 & 10.9 & 15.0 \\
\hline CR50 & 650 & 2.6 & 6.8 & 615 & 35 & 11.2 & 14.8 \\
\hline CR70 & 610 & 3.4 & 10.2 & 560 & 50 & 9.5 & 20.1 \\
\hline CR100 & 550 & 4.5 & 18.6 & 505 & 45 & 8.3 & 24.2 \\
\hline
\end{tabular}


Table 4. Mix parameters for various SCC mixes

\begin{tabular}{|c|c|c|c|c|c|c|c|}
\hline Concrete & $\begin{array}{c}\text { Initial } \\
\mathrm{FA} \\
\left(\mathrm{kg} / \mathrm{m}^{3}\right)\end{array}$ & $\begin{array}{c}\text { Post-mixing } \\
\mathrm{FA}^{*} \\
\left(\mathrm{~kg} / \mathrm{m}^{3}\right)\end{array}$ & $\begin{array}{c}\text { Initial } \\
\mathrm{CA} \\
\left(\mathrm{kg} / \mathrm{m}^{3}\right)\end{array}$ & $\begin{array}{c}\text { Post-mixing } \\
\mathrm{CA}^{\dagger} \\
\left(\mathrm{kg} / \mathrm{m}^{3}\right)\end{array}$ & $\begin{array}{c}\text { Paste } \\
\text { volume } \\
\left(\mathrm{m}^{3}\right)\end{array}$ & $\begin{array}{c}\text { Mortar } \\
\text { volume } \\
\left(\mathrm{m}^{3}\right)\end{array}$ & $\begin{array}{c}\text { Mortar } \\
\text { density } \\
\left(\mathrm{kg} / \mathrm{m}^{3}\right)\end{array}$ \\
\hline CR0 & 914 & 914 & 914 & 914 & 0.320 & 0.661 & 2218 \\
\hline CR30 & 873.8 & 894.1 & 873.8 & 853.5 & 0.320 & 0.654 & 2213 \\
\hline CR50 & 870 & 903.1 & 870 & 836.3 & 0.320 & 0.657 & 2215 \\
\hline CR70 & 866.2 & 913.2 & 866.2 & 819.2 & 0.320 & 0.661 & 2218 \\
\hline CR100 & 860.5 & 926.9 & 860.2 & 793.5 & 0.320 & 0.666 & 2221 \\
\hline
\end{tabular}

* Includes the fines generated from RCA; ${ }^{\dagger}$ excludes the fines generated from RCA; ${ }^{\star}$ per unit volume of concrete

\subsection{Filling ability}

\subsubsection{Slump flow}

The slump flow results achieved for the concrete mixes with different RCA contents are given in Table 3 . The slump flow varied in the range of $550-650 \mathrm{~mm}$. A minimum slump flow of $600 \mathrm{~mm}$ is generally recommended for SCC to ensure adequate self-consolidation capacity [12]. Therefore, the SCC mix with $100 \%$ RCA did not fulfil the requirement for slump flow. The absorption of RCA and the dosage of HRWR had no effect on the slump flow of SCC. This is because the water correction was done for the absorption of RCA and considered during concrete mixing. Also, the amount of HRWR was the same for all SCC mixes.

The effect of RCA on the slump flow of SCC is evident from Figure 3, which shows that the slump flow increased for $30 \%$ and $50 \%$ RCA. This is mainly attributed to the reduced content of coarse aggregate. Also, the post-mixing fine aggregate content was slightly lower at $30 \%$ and $50 \%$ RCA (Table 4). At the reduced fine and coarse aggregate contents, more free water was available to improve the filling ability of concrete. In addition, the paste volume was the same in all concrete mixes (Table 4). Consequently, the paste volume per unit aggregate content became higher, thus reducing the friction between aggregate particles. As a result, the dispersion of the aggregates increased leading to a greater slump flow.

The slump flow decreased for $70 \%$ and $100 \%$ RCA. In particular, the significant reduction in slump flow occurred for $100 \%$ RCA. This is in contrast with the slump flow results obtained for 30\% and 50\% RCA. The substantial decrease in slump flow at 100\% RCA is mostly due to the increased amount of fine aggregate that caused to decrease the free water content in SCC mix. The paste volume, mortar content, and mortar density had no effect in the reduction of slump flow, since these parameters were more or less similar for all SCC mixes (Table 4). But the post-mixing fine aggregate content became significantly higher for $100 \%$ RCA, as some fines (passing No. 4 sieve) were generated from RCA during abrasive mixing action (Table 4). As a result, the demand for water increased for a given slump flow. Since the water content was the same for all con- 
cretes, the SCC mix with $100 \%$ RCA provided a relatively low slump flow. A similar effect was not observed in the cases of 30\% and 50\% RCA, because the total fine aggregate content including the fines generated from RCA was still lower than that control concrete ( $0 \% \mathrm{RCA})$. In the case of $70 \% \mathrm{RCA}$, the post-mixing fine aggregate content was almost equal to that of the control concrete with $0 \%$ RCA. Yet, a slight reduction in slump flow occurred owing to the adverse physical characteristics (angularity, surface roughness, surface porosity, etc.) of RCA.

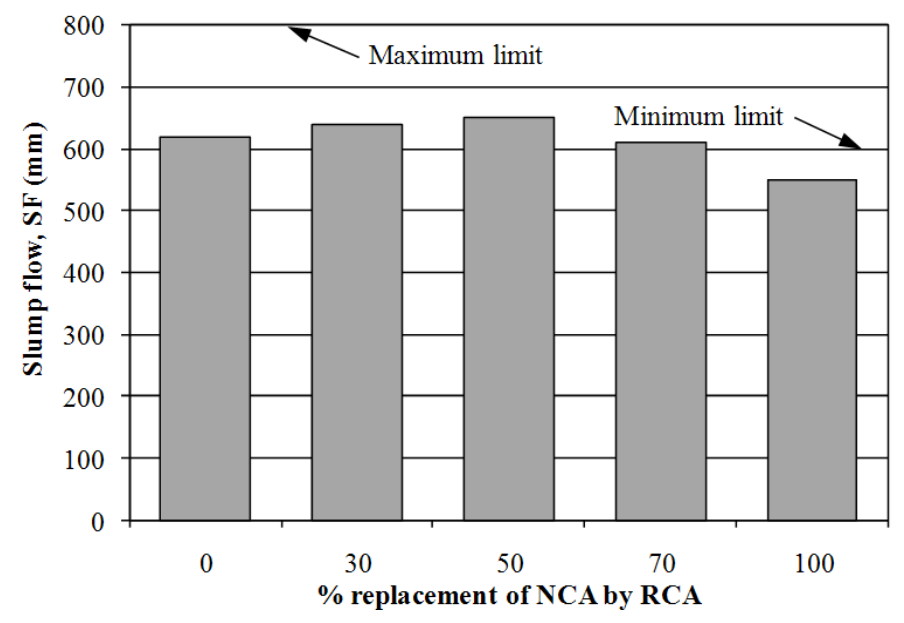

Figure 3. Effect of RCA on the slump flow of concrete

The RCA used in the present study was more angular than NCA (Table 1 and Figure 2). The high absorption capacity of RCA also indirectly suggests that it was more porous and much rougher than NCA due to reclaimed mortar. The rough-textured RCA particles increase the harshness of SCC mix, and thus can decrease its slump flow at a greater RCA content. The loss of cement paste into the surface pores of RCA can also decrease the slump flow of concrete [24]. However, these effects were not predominant due to the reduction in post-mixing coarse aggregate content with a subsequent increase in the amount of fine aggregate (Table 4).

\subsection{2. $T_{50}$ slump flow time}

The $T_{50}$ slump flow time results of the concretes with different RCA contents are given in Table 3 . The $T_{50}$ slump flow time varied in the range of 2.6-4.5 s. According to EFNARC specifications and guidelines [6], the $T_{50}$ slump flow time of SCC generally ranges from 2 to $5 \mathrm{~s}$. Hence, the $T_{50}$ slump flow times were within the acceptable range.

The effect of RCA on the $T_{50}$ slump flow time of SCC is evident from Figure 4. The $T_{50}$ slump flow time decreased for $30 \%$ and $50 \%$ RCA. This is mostly due to the 
reduced content of coarse aggregate (Table 4). However, the role of reduced coarse aggregate content in reducing $T_{50}$ slump flow time was not predominant at $70 \%$ and $100 \%$ RCA due to the similar reasons as discussed in section 4.1.1. The fine aggregate confines some mix water, thus decreasing the free water content in the concrete mix. In addition, the greater surface roughness and angularity of RCA increase the friction between coarse aggregates. These two effects were more dominant for $70 \%$ and $100 \%$ RCA. As a result, the SCC mixes with $70 \%$ and $100 \%$ RCA became more viscous and provided a higher $T_{50}$ slump flow time.

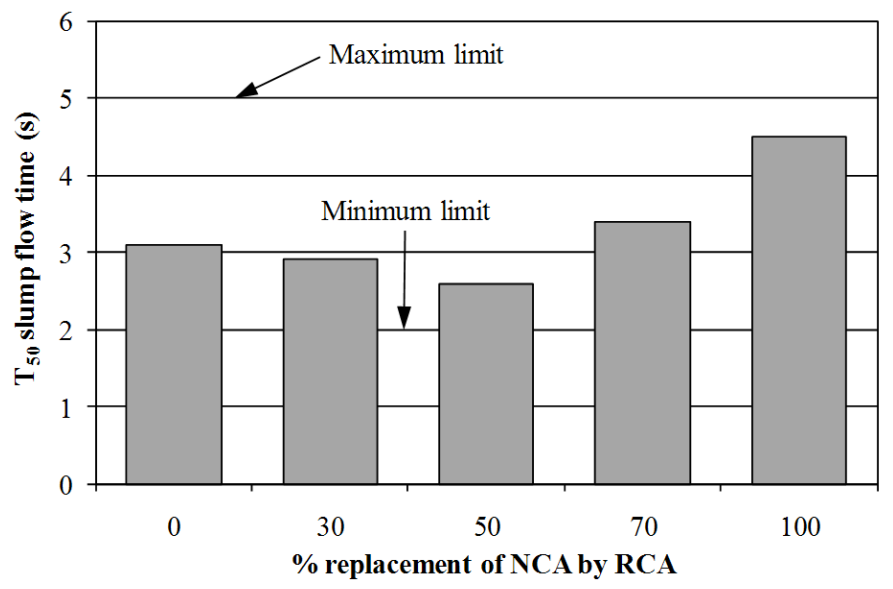

Figure 4. Effect of RCA on the $T_{50}$ slump flow time of concrete

\subsubsection{V-funnel flow time}

The V-funnel flow time results of the SCC mixes with various RCA contents are given in Table 3. The $\mathrm{V}$-funnel flow time varied in the range of 6.8-18.6 s. According to EFNARC specifications and guidelines [6], the V-funnel flow time of SCC shall be in the range of 6-12 s. Therefore, the $\mathrm{V}$-funnel flow times were within the acceptable limits except for $100 \%$ RCA. In the case of $100 \%$ RCA, the flow became intermittent with a longer flow time of concrete. A high flow time can be caused by either a low flowing ability (filling ability/passing ability) or a blockage of the flow [11]. The lack of cohesiveness can cause accumulation of coarse aggregates in the tapered outlet of a $\mathrm{V}$-funnel. This can lead to arching of coarse aggregates leading to the blockage of concrete flow. However, the good cohesiveness of CR100, as indicated by the $T_{50}$ slump flow time, suggests that the blockage due to coarse aggregate arching was unlikely for this concrete. No significant blockage was also observed in the J-ring flow test; the blocking index of CR100 was less than the maximum limit of $50 \mathrm{~mm}$ (Table 3).Therefore, the high V-funnel flow time of CR100 mix was mostly due to its low flowing ability, as perceived from the results of slump flow test. 
The variation in V-funnel flow time followed a similar trend as observed in the case of $T_{50}$ slump flow time. The effect of RCA on the V-funnel flow time of SCC is evident from Figure 5. The flow time decreased for 30\% and 50\% RCA but significantly increased for $70 \%$ and $100 \%$ RCA. The reasons are the same as discussed in the case of $T_{50}$ slump flow time (section 4.1.2). The shorter flow time indicates the greater flowing ability of concrete [6]. However, a very small flow time does not necessarily give an indication of good flowing ability. In fact, the SCC mixes with a very low V-funnel flow time show excessive bleeding and/or segregation, thus causing blockage leading to intermittent concrete flow. Also, the SCC mixes with a very high V-funnel flow time are greatly viscous and therefore may exhibit intermittent concrete flow with a reduced flowing ability. For instance, the SCC with 100\% RCA (CR100) provided a high V-funnel flow time of $18.6 \mathrm{~s}$ in the present study. This high flow time was linked with an excessive viscosity that interrupted the continuous flow of concrete through the lower opening of V-funnel.

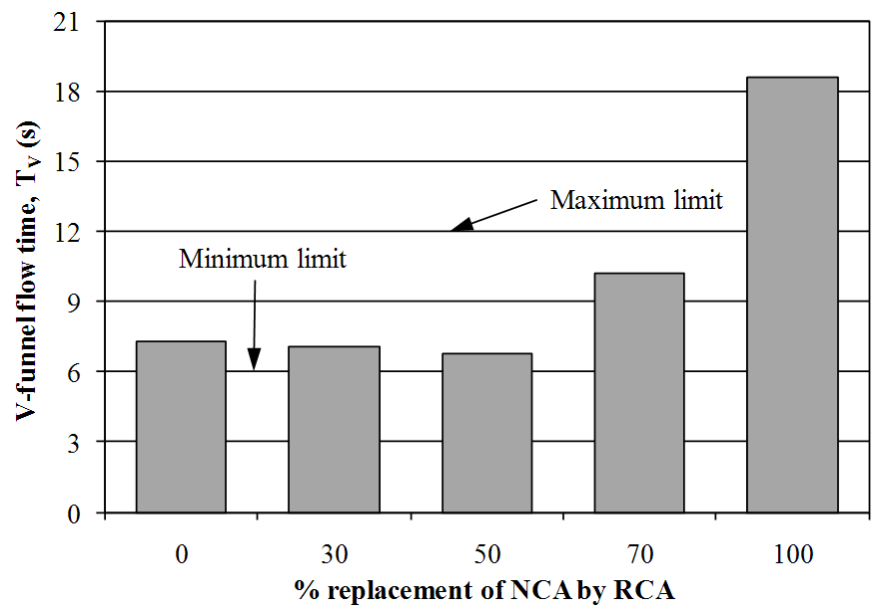

Figure 5. Effect of RCA on the V-funnel flow time of concrete

\subsection{Passing ability}

\subsubsection{J-ring flow}

The results of J-ring flow are given in Table 3. The maximum reduction in slump flow in the presence of J-ring was not greater than $50 \mathrm{~mm}$. According to Brameshuber and Uebachs [4], the difference between slump flow and J-ring flow (blocking index, SF-JF) should be $\leq 50 \mathrm{~mm}$ for SCC to ensure good passing ability without significant blockage. Hence, all SCC mixes produced in the present study possessed reasonably good passing ability.

The effect of RCA on the J-ring flow is obvious from Figure 6. This figure reveals that the passing ability was improved for $30 \%$ and 50\% RCA, since the J-ring flow 
increased. In contrast, the J-ring flow decreased at $70 \%$ and $100 \%$ RCA, thus indicating a lower passing ability. The reasons are the same as discussed in the case of slump flow (section 4.1.1). The higher replacement of NCA by RCA made the concrete harsh and increased the blocking tendency of SCC mix. At a higher content, the rough surface texture and angularity of RCA also became predominant to reduce the passing ability of SCC due to increased friction. However, no significant blockage was observed for $70 \%$ and $100 \%$ RCA although their filling ability was relatively low. It can be seen from Table 3 that the blocking index for the SCC mixes with $70 \%$ and $100 \%$ RCA was $\leq 50 \mathrm{~mm}$ (maximum limit). This is mainly credited to the reduced content of post-mixing coarse aggregate (Table 4). The reduction in coarse aggregate content with a subsequent increase in fine aggregate quantity contributed to avoid any substantial blockage.

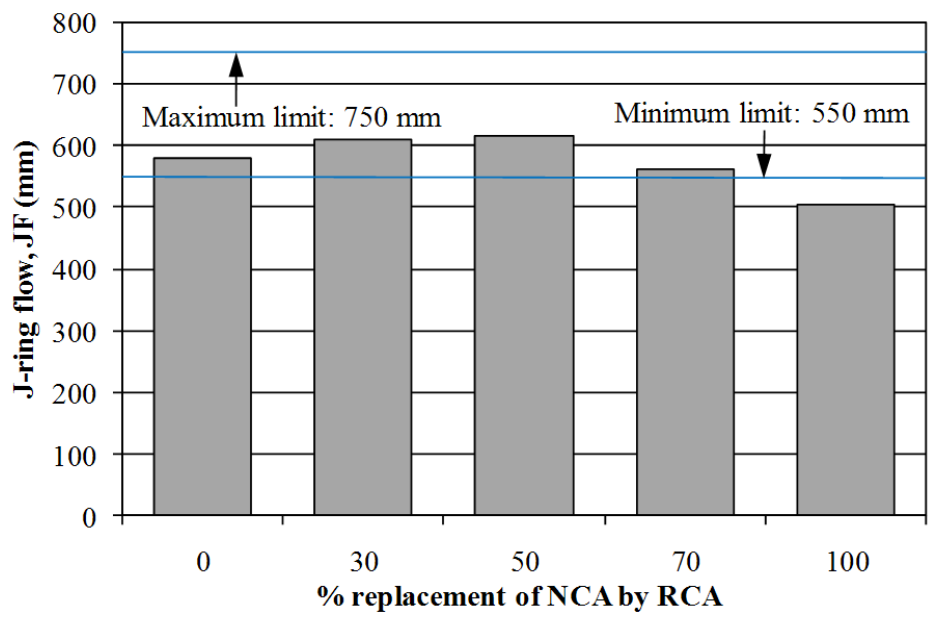

Figure 6. Effect of RCA on the J-ring flow of concrete

(Limits shown are based on slump flow limits and maximum blocking index)

\subsection{Segregation resistance}

\subsubsection{Segregation index}

The segregation indices of various SCC mixes are given in Table 3. The recommended maximum limit for segregation index is $18 \%$ [20]. In the present study, the segregation index varied in the range of $8.3-11.2 \%$. Hence, all SCC mixes had reasonably good segregation resistance according to the results of the Japanese sieve stability test.

The effect of RCA on the segregation index is apparent from Figure 7. The SCC mixes with 30\% and 50\% RCA provided a higher segregation index than the control concrete (CR0). The segregation index of control concrete was $9.8 \%$ whereas that of the SCC mixes with $30 \%$ and 50\% RCA was $10.9 \%$ and $11.2 \%$, respectively. Hence, these two SCC mixes had relatively low segregation resistance. This is due to the less cohe- 
sive nature of these two RCA concretes at a lower aggregate content (Table 4). The slump flow, $T_{50}$ slump flow time, and $\mathrm{V}$-funnel flow time results suggest that the SCC mixes with $30 \%$ and 50\% RCA possessed a lower cohesiveness than the control concrete. A less cohesive concrete mix gives a higher slump flow but a lower flow time. A decrease in the cohesiveness increases the separation of mortar, thus resulting in a higher value of segregation index. However, the segregation index was reduced at $70 \%$ and $100 \%$ RCA. This is because the greater fine aggregate content (Table 4) increased the cohesiveness of SCC mix at lower free water content. In addition, the increased angularity and surface roughness at a higher RCA content contributed to increase the cohesiveness, thus leading to a reduced segregation index.

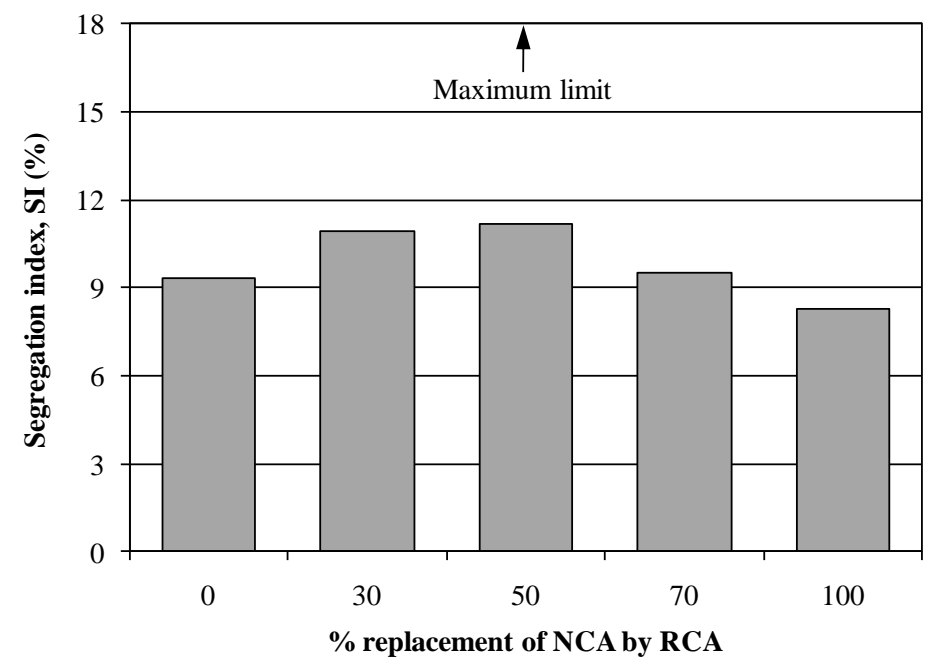

Figure 7. Effect of RCA on the segregation index of concrete

\subsubsection{Segregation ratio}

The segregation ratios of various SCC mixes are given in Table 3 . The segregation ratio varied in the range of 11.7-24.2\%. The recommended maximum limit for segregation ratio is $15 \%$ [13]. Thus, the SCC mixes with $70 \%$ and $100 \%$ RCA did not exhibit an acceptable segregation resistance, which is in contrast with the segregation index results.

The effect of RCA on the segregation ratio is clear from Figure 8. A reasonably good segregation resistance was noticed for the SCC mixes with $0 \%, 30 \%$ and $50 \%$ RCA, which provided a segregation ratio $\leq 15 \%$. In contrast, the SCC mixes with $70 \%$ and $100 \%$ RCA gave a segregation ratio significantly higher than $15 \%$. These two concrete mixes had relatively low fluidity (Table 3 ) and reduced coarse aggregate content (Table 4), which generally contribute to decrease the degree of segregation in SCC. However, the uniform distribution of coarse aggregates along the height of column apparatus can be hindered due to aggregate collisions and adverse physical characteristics of RCA when the 
fluidity is significantly low. As a result, the heterogeneity along the depth of concrete might occur during placement, thus leading to a higher value of segregation ratio.

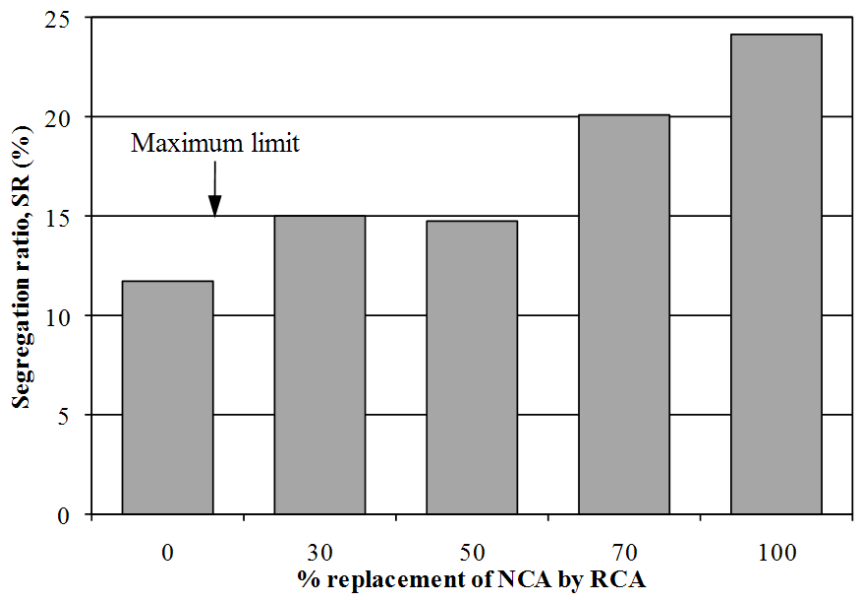

Figure 8. Effect of RCA on the segregation ratio of concrete

\subsection{Correlation between J-ring flow and slump flow}

The slump flow and J-ring flow were determined as a measure of filling ability and passing ability, respectively. The relationship between the slump flow and J-ring flow results of concrete is shown in Figure 9. It is evident from Figure 9 that the J-ring flow and slump flow of the SCC mixes were strongly correlated with a linear relationship. The correlation coefficient is 0.9909 , which points to a strong relationship.

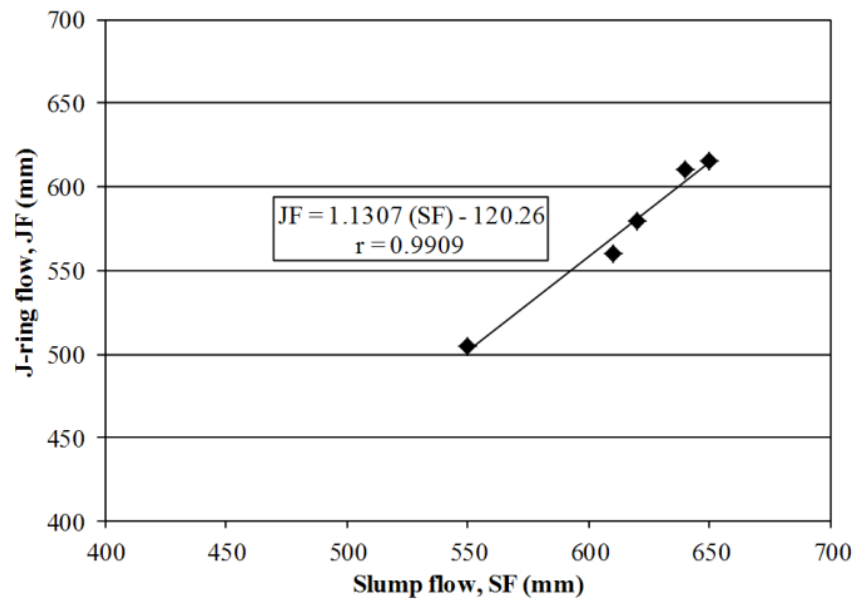

Figure 9. Correlation between J-ring flow and slump flow of concrete 
The strong correlation (Figure 9) was observed since both slump flow and J-ring flow varied similarly with the RCA content. It was also understood from such strong correlation that the filling ability and passing ability of SCC are interrelated. Therefore, it is possible to predict the passing ability of SCC based on the result of a filling ability test.

\subsection{Correlation between V-funnel flow time and $T_{50}$ slump flow time}

The relationship between $T_{50}$ slump flow time and $\mathrm{V}$-funnel flow time results is shown in Figure 10. It is obvious from Figure 10 that the $\mathrm{V}$-funnel flow time and $T_{50}$ slump flow time of the SCC mixes were strongly correlated with a linear relationship. The correlation coefficient was 0.9765 , which suggests a strong relationship. The strong correlation (Figure 10) was noticed because both $T_{50}$ slump flow time and Vfunnel flow time varied with the RCA content in a similar way. Such strong correlation implies that either $T_{50}$ slump flow or $\mathrm{V}$-funnel flow test is adequate to assess the relative viscosity and cohesiveness of SCC.

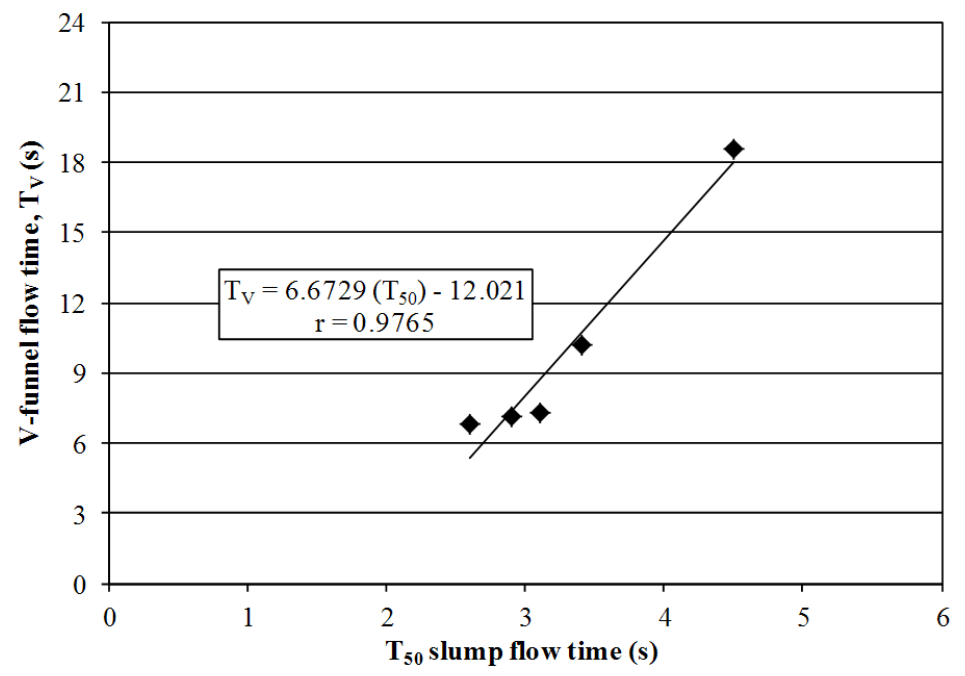

Figure 10. Correlation between V-funnel flow time and $T_{50}$ slump flow time of concrete

\subsection{Correlation between segregation index and slump flow}

The relationship between slump flow and segregation index is shown in Figure 11. It is clear from Figure 11 that the segregation index and slump flow of the SCC mixes were strongly correlated with a linear relationship. The correlation coefficient was 0.9682, which indicates a strong relationship. The strong correlation (Figure 11) was obtained since both slump flow and segregation index varied identically with the RCA 
content. Such strong correlation also suggests that slump flow can give an indication for the segregation resistance of SCC.

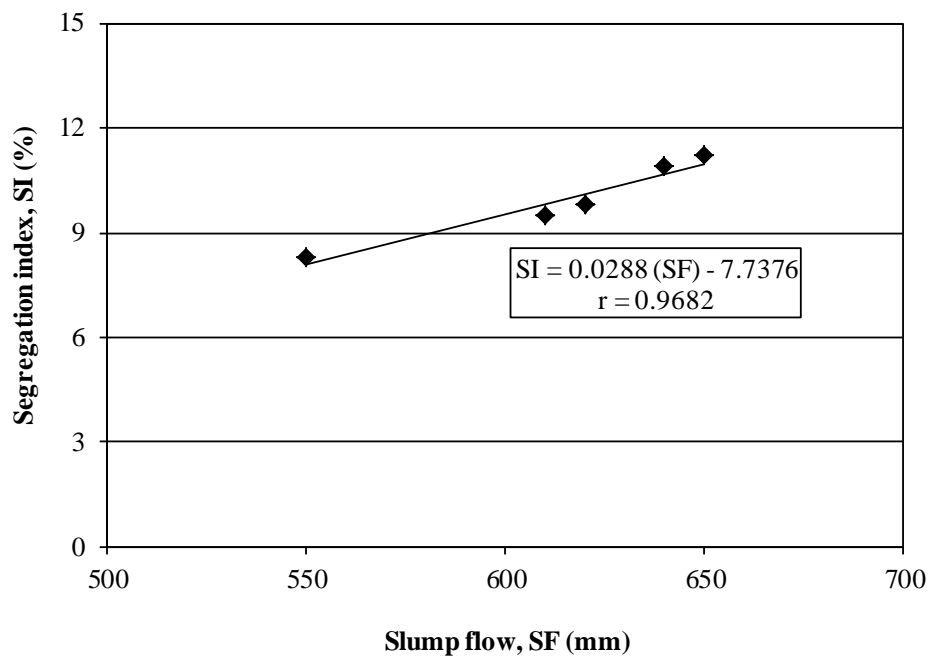

Figure 11. Correlation between segregation index and slump flow of concrete

\section{Conclusions}

The following salient conclusions can be drawn based on the findings of the present study:

1) The filling ability of SCC was improved at 30\% and 50\% RCA mainly due to reduced coarse aggregate content and relatively high paste volume per unit aggregate content. In contrast, the filling ability was reduced at a RCA content higher than $50 \%$. Particularly, a significant reduction in filling ability was observed for $100 \%$ RCA because of the increased amount of post-mixing fine aggregate.

2) The passing ability was satisfactory for all SCC mixes. A slight increase in passing ability occurred at $30 \%$ and $50 \%$ RCA due to lower coarse aggregate content. The passing ability at $70 \%$ and $100 \%$ RCA was within the recommended maximum limit although the filling ability was relatively low. This is credited to the reduction in coarse aggregate content with a subsequent increase in the quantity of fine aggregate.

3 ) The SCC mixes with a RCA content higher than $50 \%$ were more viscous as indicated by the $T_{50}$ slump flow time and $\mathrm{V}$-funnel flow time results. In particular, the high viscous nature of the SCC mix with $100 \%$ RCA was not conducive to obtain a continuous concrete flow during the $\mathrm{V}$-funnel flow test. The flow was intermittent and therefore the concrete mix required a relatively long time to flow out of the $\mathrm{V}$-funnel.

4) All SCC mixes had good segregation resistance, as noticed from the results of the Japanese sieve stability test. The segregation indices of concretes obtained from this test were significantly below the recommended maximum limit (18\%). 
However, this finding was not in agreement with all segregation ratios obtained from the column segregation test. In particular, the segregation ratios of the SCC mixes with $70 \%$ and $100 \%$ RCA were significantly higher than the recommended maximum limit (15\%) although they provided the lowest level of segregation index. The high values of segregation ratio at $70 \%$ and $100 \%$ RCA were obtained due to the significant non-uniform distribution of coarse aggregates that occurred during concrete placement mostly because of aggregate collisions at a relatively low fluidity.

5) The physical characteristics of RCA such as surface roughness, angularity, and surface porosity were not conducive to improve the fresh properties of SCC. These physical properties can act adversely to decrease the filling ability and pas sing ability of SCC at a higher content of RCA. Also, these properties may contribute to cause non-uniform distribution of coarse aggregates, thus developing the heterogeneity leading to segregation in concrete, particularly at a higher RCA content.

6) Strong correlations were observed between J-ring flow and slump flow, V-funnel flow time and $T_{50}$ slump flow time, and segregation index and slump flow due to their similar variations with the RCA content.

7) The overall test results showed that RCA can be used in SCC as a replacement of NCA up to $50 \%$ by weight without affecting the key fresh properties such as filling ability, passing ability, and segregation resistance of concrete.

\section{Acknowledgement}

The authors gratefully acknowledge the financial support through the research grant (RG 050-09AET) from the University of Malaya, Kuala Lumpur, Malaysia.

\section{References}

[1] ASTM C 33: Standard specification for concrete aggregates, Annual Book of ASTM Standards, American Society for Testing and Materials, Philadelphia, USA, 2009.

[2] ASTM C 1610/C 1610M: Standard test method for static segregation of self-consolidating concrete using column technique, Annual Book of ASTM Standards, American Society for Testing and Materials, Philadelphia, USA, 2009.

[3] ASTM C 1611/C 1611M: Standard test method for slump flow of self-consolidating concrete, Annual Book of ASTM Standards, American Society for Testing and Materials, Philadelphia, USA, 2009.

[4] Brameshuber W., Uebachs S.: Practical experience with the application of self-compacting concrete in Germany, Proceedings of the Second International Symposium on Self-Compacting Concrete, COMS Engineering Corporation, Tokyo, Japan, 2001, pp. 687-695.

[5] DoE: Design of normal concrete mixes, Department of Environment (DoE), The Building Research and Establishment (BRE) Publication, Watford, UK, 1975. 
[6] EFNARC: Specifications and guidelines for self-consolidating concrete, European Federation of Suppliers of Specialist Construction Chemicals (EFNARC), Surrey, UK, 2002.

[7] Felekoglu B., Türkel S., Baradan B.: Effect of water/cement ratio on the fresh and hardened properties of self-compacting concrete, Building and Environment, Vol. 42, No. 4, 2007, pp. 1795-1802.

[8] Grdic Z.J., Toplicic-Curcic G.A., Despotovic I.M., Ristic N.S.: Properties of self-compacting concrete prepared with coarse recycled concrete aggregate, Construction and Building Materials, Vol. 24, No. 7, 2010, pp. 1129-1133.

[9] Hendriks C.F., Pieterson H.S.: Concrete: durable but also sustainable, Proceedings of the International Conference on the Use of Recycled Concrete Aggregates, Thomas Telford, London, UK, 1998, pp. 1-18.

[10] Katz A.: Properties of concrete made with recycled aggregate from partially hydrated old concrete, Cement and Concrete Research, Vol. 33, No. 5, 2003, pp. 703-711.

[11] Khayat K.H.: Workability, testing, and performance of self-consolidating concrete, ACI Materials Journal, Vol. 96, No. 3, 1999, pp. 346-353.

[12] Khayat K.H.: Optimization and performance of air-entrained, self-consolidating concrete, ACI Materials Journal, Vol. 97, No. 5, 2000, pp. 526-535.

[13] Koehler E.P., Fowler D.W.: ICAR mixture proportioning procedure for self-consolidating concrete, International Centre for Aggregates Research, University of Texas at Austin, Texas, USA, 2006.

[14] Kou S.C., Poon C.S.: Properties of self-compacting concrete prepared with coarse and fine recycled concrete aggregates, Cement and Concrete Composites, Vol. 31, No. 9, 2009 , pp. 622-627.

[15] Levy S.M., Helene P.: Durability of recycled aggregates concrete: a safe way to sustainable development, Cement and Concrete Research, Vol. 34, No. 11, 2004, pp. 1975-1980.

[16] Nagataki S., Fujiwara H.: Self-compacting property of highly flowable concrete, Proceedings of the Second CANMET/ACI International Symposium on Advances in Concrete Technology, American Concrete Institute, Michigan, USA, 1995, pp. 301-314.

[17] Okamura H., Ouchi M.: Self-compacting concrete-development, present and future, Proceedings of the First International RILEM Symposium on Self-Compacting Concrete, RILEM Publications, Bagneux, France, 1999, pp. 3-14.

[18] Okamura H., Ouchi M.: Self-compacting concrete, Journal of Advanced Concrete Technology, Vol. 1, No. 1, 2003, pp. 5-15.

[19] Ozawa K., Mackawa K., Okamura H.: High performance concrete based on the durability design of concrete structures, Proceedings of the Second East Asia Pacific Conference on Structural Engineering and Construction, Chiang-Mai, Thailand, 1989, pp. 445-450.

[20] Parez N., Romero H., Hermida G., Cuellar G.: Self-compacting concrete, on the search and finding of an optimized design, Proceedings of the First North American Conference on the Design and Use of Self-Consolidating Concrete, Hanley-Wood, LLC, Illinois, USA, 2002, pp. 101-107.

[21] Poon C., Kou S., Lam L.: Influence of recycled aggregate on slump and bleeding of fresh concrete, Materials and Structures, Vol. 40, No. 9, 2007, pp. 981-988.

[22] Portland Cement Association: Recycled aggregate, Concrete Technology, Available from http://www.cement.org/tech/cct_aggregates_recycled.asp, Access in May 13, 2010. 
[23] Sagoe-Crentsil K.K., Brown T., Taylor A.H.: Performance of concrete made with commercially produced coarse recycled concrete aggregate, Cement and Concrete Research, Vol. 31, No. 5, 2001, pp. 707-712.

[24] Su N., Wang B.L.: Study on the engineering properties of recycled aggregate concrete and recovered aggregate from demolished concrete, Journal of the Chinese Institute of Civil and Hydraulic Engineering, Vol. 12, No. 3, 2000, pp. 435-444.

[25] Tang L.: Evaluation of methods for testing fresh self-compacting concrete, Proceedings of the First International Symposium on Design, Performance and Use of SelfConsolidating Concrete, Changsha, China, 2005, pp. 245-252.

[26] Tu T.-Y., Chen Y.-Y., Hwang C.-L.: Properties of HPC with recycled aggregates, Cement and Concrete Research, Vol. 36, No. 5, 2006, pp. 943-950.

[27] Tu T.-Y., Jann Y.-Y., Hwang C.-L.: The application of recycled aggregates in SCC, Proceedings of the First International Symposium on Design, Performance and Use of Self-Consolidating Concrete, Changsha, China, 2005, pp. 145-152.

[28] Zakaria M., Cabrera J.G.: Performance and durability of concrete made with demolition waste and artificial fly ash-clay aggregates, Waste Management, Vol. 16, Nos. 1-3, 1996, pp. 151-158.

\section{Wpływ kruszywa uzyskanego z recyklingu betonu na właściwości świeżego betonu samozagęszczalnego}

Odpady betonowa są dostarczane zazwyczaj na składowiska odpadów w celu utylizacji. Ze względu na rosnące koszty składowania, a zarazem niedostatek naturalnego kruszywa grubego (NCA), kruszywowa uzyskane z recyklingu betonu (RCA) i pochodzące z odpadów betonowych zyskuje coraz większe zainteresowanie w branży budowlanej. W niniejszej pracy analizowane jest wykorzystanie RCA w postaci częściowego jaki i pełnego zastąpienie kruszywa NCA do produkcji betonu samozagęszczalnego (SCC). W pracy przeanalizowano wpływ RCA na kluczowe właściwości świeżego betonu SCC. Ogólne wyniki badań wskazują, że RCA może być użyty do produkcji SCC przy zastąpieniu przez niego do 50\% NCA bez wpływu na kluczowe właściwości świeżego betonu. 